\title{
Impact of Cafeteria Diet on the Composition of Fatty Acids in Zebrafish (Danio rerio) Fillets
}

\author{
Vanessa B. M. J. C. Néia, ${ }^{a}$ Eliane P. Ambrosio-Albuquerque, ${ }^{b}$ Ingrid L. Figueiredo, ${ }^{c}$ \\ Joana S. Boeing, ${ }^{c}$ Thibério C. da Silva, ${ }^{d}$ Vanessa Lewandowski, ${ }^{d}$ Ricardo P. Ribeiro, ${ }^{d}$ \\ Jeane E. L. Visentainer ${ }^{r}$ and Jesuí V. Visentainer*,c
}

${ }^{a}$ Pós-Graduação em Ciência de Alimentos, Universidade Estadual de Maringá, Av. Colombo, 5790, 87020-900 Maringá-PR, Brazil,

${ }^{b}$ Departamento de Biotecnologia, Genética e Biologia Celular, Universidade Estadual de Maringá, Av. Colombo, 5790, 87020-900 Maringá-PR, Brazil

'Departamento de Química, Universidade Estadual de Maringá, Av. Colombo, 5790, 87020-900 Maringá-PR, Brazil

${ }^{d}$ Departamento de Zootecnia, Universidade Estadual de Maringá, Av. Colombo, 5790, 87020-900 Maringá-PR, Brazil

eDepartamento de Ciências Básicas da Saúde, Laboratório de Imunogenética, Universidade Estadual de Maringá, Av. Colombo, 5790, 87020-900 Maringá-PR, Brazil

\begin{abstract}
The cafeteria diet is widely used as a model for inducing obesity in animals, and the zebrafish (Danio rerio) has emerged as a promising model for this purpose. In this context, this study evaluated the effect of a cafeteria diet on the composition of fatty acids in zebrafish fillets. Zebrafish grown in tanks for a period of 60 days were treated with standard (ST) and cafeteria (CAF) diets. The CAF diet presented higher total lipid and energy values than ST diet, due to the addition of peanut, chocolate and biscuit in its preparation. Moreover, CAF diet showed the highest concentrations of palmitic $\left(19.44 \pm 0.55 \mathrm{mg} \mathrm{g}^{-1}\right)$, oleic $\left(102.58 \pm 2.85 \mathrm{mg} \mathrm{g}^{-1}\right)$ and linoleic $\left(44.47 \pm 1.32 \mathrm{mg} \mathrm{g}^{-1}\right)$ acids. A significant increase in oleic and linoleic acid concentrations $\left(39.77 \pm 2.69\right.$ and $14.31 \pm 0.86 \mathrm{mg} \mathrm{g}^{-1}$, respectively) and in the omega-6/omega-3 ratio (11.52 \pm 0.81 ) was observed in the zebrafish fillets between 0 and 60 days for CAF diet, indicating incorporation of these fatty acids.
\end{abstract}

Keywords: obesity, cafeteria diet, Danio rerio, fatty acids, lipid composition

\section{Introduction}

Obesity is defined as an accumulation of abnormal or excessive fat that can harm health. The mainly cause of overweight and obesity is an energy imbalance between calories expended and calories consumed. ${ }^{1}$ Human obesity finds itself in a global epidemic that affects more than 600 million people in industrialized countries. ${ }^{2,3}$ This is particularly alarming given the association of the obesity and several pathological conditions, ${ }^{4}$ such as type 2 diabetes, ${ }^{5}$ atherosclerosis, ${ }^{4}$ hypertension, ${ }^{6}$ cardiovascular disease, ${ }^{7}$ hyperlipidemia and certain types of cancer, ${ }^{2,5}$ which make obesity a major risk factor for global mortality. ${ }^{8}$

*e-mail: jesuiv@gmail.com
Obesity is caused by genetic and environmental factors that result in an imbalance between the energy consumed and spent. ${ }^{3}$ In humans, increasing access to high-fat and high-calorie diets is considered a major contributor to obesity. ${ }^{8}$ Total and saturated fat consumption has increased significantly in Western diets in the last decades. On the other hand, there was a decrease in consumption of omega- 3 and an increase in omega- 6 fatty acids consumption, resulting in an imbalance in the omega-6/ omega-3 ratio that was $1: 1$ during evolution and is currently 20:1. The significant increase of overweight and obesity is directly related to this alteration in the composition of fatty acids. ${ }^{9}$

In general, regardless of genetic or metabolic dysfunctions, obese individuals regularly consume diets with high fat and calories. This type of diet is known as 
cafeteria diet (CAF). ${ }^{10}$ The CAF diet is widely used to induce obesity in animals by allowing that animals choose the type of food with high fat, energy and sugar, they wish to eat. The CAF diet is a very relevant model of obesity induction because it covers a variety of highly palatable and energy-dense foods that are accessible in Western societies and which are directly related to obesity in humans. ${ }^{2}$

In experimental animal studies, several models of dietinduced obesity have been used to study the etiology of obesity, aiming to gain better understanding of molecular mechanisms and possible treatments. In this context, zebrafish (Danio rerio) emerged as a model for studies of obesity due to its physiology similar to humans, especially its unique advantages in biology, genomics and genetics. ${ }^{8,11}$ In addition, the lipid and endocrine metabolic pathways that regulate energetic homeostasis are similar between mammals and zebrafish. ${ }^{6-12}$

Frequently, the obesity induction studies in zebrafish use Artemia or Artemia cysts as a food source to induce weight gain in these animals; ${ }^{3,4,13}$ and the CAF diet remains relatively unexplored, even though it is a common diet used in mammal models. In this context, we evaluated, for the first time, the effect of a CAF diet on the composition of fatty acids in zebrafish fillets over 60 days.

\section{Experimental}

\section{Experimental diets}

Two experimental diets, standard (ST) and cafeteria (CAF), were formulated according to Siccardi et al. ${ }^{14}$ The CAF diet contained: ST (37.5\%), peanut $(25 \%)$, chocolate $(25 \%)$ and biscuit $(12.5 \%)$. The feed ingredients were milled, sieved, mixed and pelletized $(<3 \mathrm{~mm}$ diameter). Pellets were dried in an oven with air circulation at $55^{\circ} \mathrm{C}$ for $10 \mathrm{~h}$. The experimental diets were vacuum-packed and kept at $-18^{\circ} \mathrm{C}$ until use in fish feeding. Formulation and chemical composition of experimental diets are shown in Table 1.

\section{Chemical composition}

Moisture, ash and protein contents, for both diets, were determined in accordance with the Association of Official Analytical Chemists (AOAC). ${ }^{15}$ Total lipid contents of experimental diets were extracted according to Bligh and Dyer. ${ }^{16}$ The values of carbohydrates were estimated by differences, and the energy values of the experimental diets were calculated according to conversion factors (carbohydrates 4, 4 and $9 \mathrm{kcal} \mathrm{g}^{-1}$ for carbohydrates, crude protein and total lipids, respectively).
Table 1. Formulation and chemical composition of experimental diets

\begin{tabular}{|c|c|c|}
\hline \multirow{2}{*}{ Ingredient } & \multicolumn{2}{|c|}{ Experimental diet / \% } \\
\hline & Standard diet & Cafeteria diet \\
\hline Soy protein isolate & 50.53 & 18.95 \\
\hline Grain corn & 9.41 & 3.53 \\
\hline Gluten maize & 20 & 7.50 \\
\hline Sunflower oil & 8 & 3.00 \\
\hline Rice & 5 & 1.88 \\
\hline Dicalcium phosphate & 3.61 & 1.35 \\
\hline Lysine & 1.51 & 0.57 \\
\hline Premix & 1 & 0.38 \\
\hline Methionine & 0.43 & 0.16 \\
\hline Limestone & 0.43 & 0.16 \\
\hline Salt & 0.3 & 0.11 \\
\hline Tryptophan & 0.09 & 0.03 \\
\hline Peanut & 0 & 25.00 \\
\hline Chocolate & 0 & 25.00 \\
\hline Biscuit & 0 & 12.50 \\
\hline \multicolumn{3}{|l|}{ Chemical composition $^{\mathrm{a}}$} \\
\hline Ash & $5.81 \pm 0.02^{\mathrm{a}}$ & $3.31 \pm 0.01^{\mathrm{b}}$ \\
\hline Crude protein & $49.89 \pm 0.38^{\mathrm{a}}$ & $28.55 \pm 0.61^{\mathrm{b}}$ \\
\hline Moisture & $2.12 \pm 0.06^{\mathrm{a}}$ & $2.30 \pm 0.02^{\mathrm{b}}$ \\
\hline Total lipids & $16.13 \pm 2.94^{\mathrm{a}}$ & $32.36 \pm 4.77^{\mathrm{b}}$ \\
\hline Carbohydrate & $26.03 \pm 2.61^{\mathrm{a}}$ & $33.46 \pm 4.19^{\mathrm{a}}$ \\
\hline Energetic value / (kcal per $100 \mathrm{~g}$ ) & $448.92 \pm 14.45^{\mathrm{a}}$ & $539.34 \pm 23.89^{\mathrm{b}}$ \\
\hline
\end{tabular}

${ }^{a}$ Results expressed as mean \pm standard deviation for analysis in three replicates. Means followed by distinct letters in the same row are significantly different by $t$-test $(p<0.05)$.

\section{Feeding trial and fish sampling}

This work was conducted in the PeixeGen Laboratory of the State University of Maringá (Maringá city, Paraná, Brazil), from August to October 2016. Five-week-old male zebrafish weighing $0.48 \pm 0.07 \mathrm{~g}$ were used. Forty fish were divided equally and randomly into two groups, according to the CAF or ST diets, in tanks with a capacity of $40 \mathrm{~L}$ water flow, constant oxygenation and external activated carbon filtration. Prior to the experiment, the fish received the ST diet for a period of 15 days for adaptation. After this period, ten fish from each tank were removed for zero-time (0 days) analyses. After that, the experiment was initiated by providing the CAF and ST diets. The fish were fed four times a day ad libitum. ${ }^{17,18}$ After 60 days of feeding, the zebrafish were euthanized and the fillets were collected. The fillets were kept in polyethylene bags and stored at $-18^{\circ} \mathrm{C}$ until analysis. At the beginning of each analysis the 
samples were homogenized. All animal experiments were carried out in accordance with the regulations approved by the Ethics Committee on the Use of Animals of the State University of Maringá (CEUA No. 5133220616 from the meeting on 08/07/2016).

\section{Fatty acid composition}

The fatty acid methyl esters (FAMEs) of the experimental diets and fish fillets were prepared by total lipid methylation as described by Figueiredo et al. ${ }^{19} \mathrm{In}$ this procedure, $100 \mathrm{mg}$ of experimental diets and homogenized fillets were weighed in glass tubes with $10 \mathrm{~cm}$ capacity. Then $2.0 \mathrm{~mL}$ of $\mathrm{NaOH}$ (1.5 $\mathrm{mol} \mathrm{L}^{-1}$ in methanol) was added, and the sample was macerated with a glass rod. Posteriorly, the test tubes were placed in an Eco-Sonics Q5.9/25 ultrasonic bath (Unique, São Paulo, Brazil) for $5 \mathrm{~min}$ at $30^{\circ} \mathrm{C}$. After this reaction, $2.0 \mathrm{~mL}$ of $\mathrm{H}_{2} \mathrm{SO}_{4}\left(1.5 \mathrm{~mol} \mathrm{~L}^{-1}\right.$ in methanol) was added, and the test tube was again placed in the ultrasonic bath for $5 \mathrm{~min}$ at $30^{\circ} \mathrm{C}$. Then $1.0 \mathrm{~mL}$ of $n$-heptane was added, and the tubes were shaken for $30 \mathrm{~s}$ and centrifuged at $2000 \mathrm{rpm}$ for $1 \mathrm{~min}$. Finally, $500 \mu \mathrm{L}$ of internal standard (methyl ester of tricosanoic acid, 23:0me) was added, and the supernatant containing the FAMEs was collected.

FAMEs separation were conducted by gas chromatography in a Thermo Scientific Trace ${ }^{\text {TM }}$ Ultra 3300 Gas Chromatograph (Waltham, United States) equipped with a flame ionization detector (FID), a split/splitless injector and a CP-7420 fused silica capillary column (Select FAME, $100 \mathrm{~m}$ size, $0.25 \mathrm{~mm}$ internal diameter and $0.25 \mu \mathrm{m}$ film thickness of the cyanopropyl stationary phase). The operation parameters were: column temperature of $165{ }^{\circ} \mathrm{C}$ for $18 \mathrm{~min}$ and then raised to $235^{\circ} \mathrm{C}$ at a rate of $4{ }^{\circ} \mathrm{C} \mathrm{min}-1$ for $20 \mathrm{~min}$. The injector and detector port temperatures were 230 and $250{ }^{\circ} \mathrm{C}$, respectively. The gas flows were $1.2 \mathrm{~mL} \mathrm{~min}^{-1}$ for the carrier gas $\left(\mathrm{H}_{2}\right) ; 30 \mathrm{~mL} \mathrm{~min}^{-1}$ for the make-up gas $\left(\mathrm{N}_{2}\right)$; $30 \mathrm{~mL} \mathrm{~min}^{-1}$ for the FID gas $\left(\mathrm{H}_{2}\right)$; and $300 \mathrm{~mL} \mathrm{~min}^{-1}$ for the synthetic air. The injection volume of sample was $1 \mu \mathrm{L}$ in a split injection at 1:40 ratio. FAMEs were identified by comparing their retention times with those of standard methyl esters (Sigma, St. Louis, USA).

Quantification of fatty acids ( $\mathrm{mg} \mathrm{g}^{-1}$ of sample) was made using 23:0me and theoretical FID correction factor values were used according to Visentainer. ${ }^{20}$

\section{Statistical analysis}

All analyses were carried out in triplicate and the results (mean \pm standard deviation, SD) were submitted to one-way analysis of variance (ANOVA) at 5\% significance level using GraphPad Prism ${ }^{\circledR}$ v. 5.0 software. ${ }^{21}$ The mean values of chemical and fatty acid composition of the experimental diets were compared by $t$-test and the fatty acid composition of the zebrafish fillets was compared by Tukey's test.

\section{Results and Discussion}

The CAF and ST diets were well accepted by the fish and there were no deaths due to dietary intake of either treatment. As shown in Table 1 there was a significant difference in the chemical composition of the experimental diets, except for carbohydrate values. The CAF diet presented higher total lipid $(32.36 \pm 4.77 \%)$ and energy $(539.34 \pm 23.99 \%)$ values than the ST diet, due to the addition of peanut, chocolate and biscuit in its preparation, foodstuffs with high fat/energy. ${ }^{22,23}$ It was observed that the CAF diet presented a higher proportion of fat in its composition when compared to the ST diet; this was also observed in studies conducted by Zeeni et al., ${ }^{2}$ Suárez-García et al. ${ }^{24}$ and Cardoso et al. ${ }^{25}$ In our study, peanut, chocolate and biscuit were used to increase the caloric density of the CAF diet; other studies used bacon, ${ }^{10,24,25}$ sweets, ${ }^{25}$ biscuits, ${ }^{2,24,25}$ chocolate, ${ }^{2}$ cookies, ${ }^{10}$ sweet roll ${ }^{24}$ and peanut butter. ${ }^{2}$ Although the basis of all CAF diets is high fat and calories, their composition is very different, not having a standard regarding the amount and composition of the food. However, CAF diets always follow the addition of some types of food like peanuts, chocolate, crackers, soft drinks, cakes, condensed milk, bacon and sausage added to the standard animal diet. This occurs similarly in humans that consume hypercaloric foods, ingesting calories and fats above their metabolic need, leading to obesity. ${ }^{8}$

In this study it was observed that the CAF diet presented $53.99 \%$ total energy as fat, while the ST diet presented $32.33 \%$ total energy as fat. This ratio of more dietary fat may lead to greater obesity; in general, diets containing more than $30 \%$ of total energy as fat lead to the development of obesity. ${ }^{26}$ In humans, there is a significant positive relationship between the consumption of high-fat foods and the proportion of the overweight population. These associations have also been demonstrated in animal studies. ${ }^{2,10,24,25}$ One of the key factors driving the worldwide rise in obesity is related to changes in eating habits, including increased energy-dense foods. In this context, the CAF diet model induces obesity in animals using high-caloric foods in order to reflect the eating habits of Western societies that have relevance in increasing obesity in humans. ${ }^{2}$

Table 2 presents the fatty acid composition of the experimental diets used in this study. 
Table 2. Fatty acid composition of experimental diets

\begin{tabular}{|c|c|c|}
\hline \multirow{2}{*}{ Fatty acid } & \multicolumn{2}{|c|}{ Experimental diet / ( $\mathrm{mg} \mathrm{g}^{-1}$ of sample) } \\
\hline & Standard diet & Cafeteria diet \\
\hline 16:0 & $7.96 \pm 0.25^{\mathrm{a}}$ & $19.44 \pm 0.55^{\mathrm{b}}$ \\
\hline 16:1n-9 & $0.02 \pm 0.01^{\mathrm{a}}$ & $0.07 \pm 0.01^{\mathrm{b}}$ \\
\hline $16: 1 \mathrm{n}-7$ & $0.09 \pm 0.01^{\mathrm{a}}$ & $0.17 \pm 0.01^{\mathrm{b}}$ \\
\hline 18:0 & $2.24 \pm 0.08^{\mathrm{a}}$ & $6.24 \pm 0.13^{b}$ \\
\hline 18:1n-9 & $26.38 \pm 0.42^{\mathrm{a}}$ & $102.58 \pm 2.85^{\mathrm{b}}$ \\
\hline $18: 1 \mathrm{n}-7$ & $0.71 \pm 0.06^{\mathrm{a}}$ & $1.37 \pm 0.07^{\mathrm{b}}$ \\
\hline $18: 2 n-6$ & $32.39 \pm 0.90^{\mathrm{a}}$ & $44.47 \pm 1.32^{\mathrm{b}}$ \\
\hline $18: 3 n-6$ & $0.48 \pm 0.05^{\mathrm{a}}$ & $0.60 \pm 0.02^{\mathrm{b}}$ \\
\hline 20:0 & $0.32 \pm 0.02^{\mathrm{a}}$ & $1.55 \pm 0.04^{\mathrm{b}}$ \\
\hline $20: 1 n-9$ & $0.26 \pm 0.02^{\mathrm{a}}$ & $1.91 \pm 0.03^{\mathrm{b}}$ \\
\hline 22:0 & $0.30 \pm 0.02^{\mathrm{a}}$ & $2.84 \pm 0.10^{\mathrm{a}}$ \\
\hline $24: 0$ & nd & $1.69 \pm 0.08$ \\
\hline$n-6$ & $32.88 \pm 0.9^{\mathrm{a}}$ & $45.07 \pm 1.3^{\mathrm{b}}$ \\
\hline SFA & $10.83 \pm 0.3^{\mathrm{a}}$ & $31.78 \pm 0.9^{\mathrm{b}}$ \\
\hline MUFA & $27.47 \pm 0.5^{\mathrm{a}}$ & $106.12 \pm 3.0^{b}$ \\
\hline PUFA & $32.88 \pm 0.9^{\mathrm{a}}$ & $45.07 \pm 1.3^{\mathrm{b}}$ \\
\hline PUFA/SFA & $3.03 \pm 2.5250^{\mathrm{a}}$ & $1.41 \pm 1.5^{\mathrm{b}}$ \\
\hline PUFA/MUFA & $1.19 \pm 1.8^{\mathrm{a}}$ & $0.42 \pm 0.5^{\mathrm{b}}$ \\
\hline
\end{tabular}

Results expressed as mean \pm standard deviation for analysis in three replicates. Values with different letters in the same row are significantly different $(p<0.05)$ by $t$-test; nd: not detected; SFA: total saturated fatty acid; MUFA: total monounsaturated fatty acid; PUFA: total polyunsaturated fatty acid; $n-6$ : total omega- 6 fatty acid.

A total of 12 fatty acids were found in the CAF diet and 11 in the ST diet. The major saturated (SFA), monounsaturated (MUFA) and polyunsaturated (PUFA) fatty acids in both diets were palmitic (16:0), oleic (18:1n-9) and linoleic (18:2n-6) acids, respectively. The CAF diet presented higher concentrations of palmitic $\left(19.44 \pm 0.55 \mathrm{mg} \mathrm{g}^{-1}\right)$, oleic $\left(102.58 \pm 2.85 \mathrm{mg} \mathrm{g}^{-1}\right)$ and linoleic $\left(44.47 \pm 1.32 \mathrm{mg} \mathrm{g}^{-1}\right)$ acids than ST diet, due to the use of chocolate, biscuit and peanut in its preparation (Table 1). Chocolate and biscuit are sources of palmitic and linoleic acid ${ }^{22}$ and peanut is a source of oleic acid, ${ }^{23}$ confirming the transfer of fatty acids to the CAF diet. SFA were found in the highest concentration in the CAF diet, three times higher than the concentration found in the ST diet.

The relevant fatty acids in this study are those belonging to the n-3 (omega-3) and n-6 (omega-6) PUFA series. Alpha-linolenic (18:3n-3) and linoleic (18:2n-6) acids are the precursors of the $n-3$ and $n-6$ series, respectively; ${ }^{27}$ however, alpha-linolenic acid was not detected in both diets in this study. Recent study by Simopoulos ${ }^{9}$ has shown that in humans the increase of omega- 6 and omega- 3 fatty acids ratio (greater than 2:1) is related to increase development of obesity.
Another important factor is the amount of MUFA in the CAF diet, which is 4.5 times higher than in the ST diet, and corresponding to $57 \%$ of total fatty acids. Brunetti et al..$^{28}$ and Zeeni $e t$ al. $^{2}$ used the CAF diet as a model of induced obesity in mice and found MUFA values of 77.27 and 55\%, respectively, similar to our results.

After the administration period of the experimental diets, 26 fatty acids were identified and quantified in zebrafish fillets, as shown in Table 3.

The same classes of fatty acids, SFA, MUFA, and PUFA, were found in fillets and diets. Palmitic acid (16:0) was the SFA found in the highest concentration. For MUFA and PUFA, oleic (18:1n-9) and linoleic (18:2n-6) acids were found in the highest concentrations, respectively. The CAF diet increased the palmitic acid content in zebrafish fillets 1.2 times, from 9.58 ( 0 days of supplementation) to $12.05 \mathrm{mg} \mathrm{g}^{-1}$ (60 days of supplementation). Palmitic acid (16:0) is generally considered to be the most abundant SFA in nature; it is found in appreciable amounts in the lipids of animals, plants and lower organisms ${ }^{29}$ and, in particular, it is a nutrient that generates metabolic changes resulting in inflammation that probably contribute to obesity. ${ }^{30}$

The CAF diet increased the MUFA content in zebrafish fillets 1.9 times, from 23.0 (0 days of supplementation) to $44.24 \mathrm{mg} \mathrm{g}^{-1}$ (60 days of supplementation). Delgado et $_{\text {al. }}{ }^{31}$ assessed 975 patients for association between MUFA and all-cause mortality from cardiovascular diseases for 10 years, and found an association between oleic acid intake and mortality reaching $14 \%$ of subjects.

The levels of eicosapentaenoic acid (20:5n-3) and docosahexaenoic acid (22:6n-3), which are important long-chain polyunsaturated fatty acids (LC-PUFA), decreased over the 60 days of supplementation in zebrafish fillets, although we observed an increase in the concentration of arachidonic acid (20:4n-6) and the essential alpha-linolenic and linoleic acids, which are precursors of the n- 3 and n- 6 fatty acids series, respectively.

The zebrafish fillets presented an increase in the $n-6 / n-3$ and PUFA/SFA ratios in the different periods of supplementation. A diet with a high omega-6/omega-3 ratio generates an increase in endocannabinoid signaling and related mediators, which causes an increased inflammatory state, homeostasis, and energy mood; in animal modeling experiments, a high intake of omega- 6 acids leads to decreased insulin sensitivity in the muscle and promotes the accumulation of fat in adipose tissue. ${ }^{9}$ The PUFA/SFA values are not in line with Simopoulos ${ }^{32}$ recommendations, which stated that values below 0.4 are not adequate for health in relation to the prevention of heart disease. The CAF diet decreased the omega-3 polyunsaturated fatty acid (n-3 PUFA) content 0.5 times in zebrafish fillets, from 
Table 3. Fatty acid composition of zebrafish fillets submitted to different experimental diets

\begin{tabular}{|c|c|c|c|}
\hline \multirow{2}{*}{ Fatty acid } & \multirow{2}{*}{$\begin{array}{c}\mathrm{t}=0 \text { days } \\
\mathrm{ST} /\left(\mathrm{mg} \mathrm{g}^{-1} \text { of sample }\right)\end{array}$} & \multicolumn{2}{|c|}{$\mathrm{t}=60$ days } \\
\hline & & ST / ( $\mathrm{mg} \mathrm{g}^{-1}$ of sample $)$ & $\mathrm{CAF} /\left(\mathrm{mg} \mathrm{g}^{-1}\right.$ of sample $)$ \\
\hline 12:0 & $0.35 \pm 0.03^{\mathrm{a}}$ & $0.38 \pm 0.01^{\mathrm{a}}$ & $0.30 \pm 0.01^{\mathrm{b}}$ \\
\hline 14:0 & $0.08 \pm 0.00^{\mathrm{a}}$ & $0.06 \pm 0.01^{\mathrm{b}}$ & $0.07 \pm 0.00^{\mathrm{b}}$ \\
\hline 15:0 & $0.10 \pm 0.01^{\mathrm{a}}$ & $0.09 \pm 0.01^{\mathrm{a}}$ & $0.12 \pm 0.01^{\mathrm{b}}$ \\
\hline $15: 1 n-9$ & $0.14 \pm 0.01^{\mathrm{a}}$ & $0.14 \pm 0.01^{\mathrm{a}}$ & $0.11 \pm 0.01^{\mathrm{b}}$ \\
\hline $15: 1 n-7$ & $0.03 \pm 0.01$ & $0.03 \pm 0.01^{\mathrm{a}}$ & $0.04 \pm 0.01^{\mathrm{a}}$ \\
\hline $16: 0$ & $9.58 \pm 0.75^{\mathrm{a}}$ & $9.02 \pm 0.19^{\mathrm{a}}$ & $12.05 \pm 0.71^{\mathrm{b}}$ \\
\hline $16: 1 n-9$ & $0.34 \pm 0.02^{\mathrm{a}}$ & $0.41 \pm 0.02^{\mathrm{b}}$ & $0.58 \pm 0.03^{c}$ \\
\hline $16: 1 n-7$ & $1.12 \pm 0.09^{\mathrm{a}}$ & $0.86 \pm 0.04^{b}$ & $1.04 \pm 0.05^{\mathrm{a}}$ \\
\hline $16: 1 n-5$ & $0.23 \pm 0.02^{\mathrm{a}}$ & $0.23 \pm 0.02^{\mathrm{a}}$ & $0.31 \pm 0.02^{\mathrm{b}}$ \\
\hline $17: 0$ & $0.24 \pm 0.02^{\mathrm{a}}$ & $0.20 \pm 0.01^{\mathrm{b}}$ & $0.27 \pm 0.02^{\mathrm{b}}$ \\
\hline 17:1n-9 & $0.14 \pm 0.01^{\mathrm{a}}$ & $0.10 \pm 0.01^{\mathrm{a}}$ & $0.14 \pm 0.01^{\mathrm{b}}$ \\
\hline $17: 1 \mathrm{n}-7$ & $0.16 \pm 0.01^{\mathrm{a}}$ & $0.11 \pm 0.01^{\mathrm{a}}$ & $0.13 \pm 0.01^{\mathrm{b}}$ \\
\hline 18:0 & $3.34 \pm 0.20^{\mathrm{a}}$ & $2.61 \pm 0.02^{\mathrm{b}}$ & $3.37 \pm 0.16^{\mathrm{a}}$ \\
\hline 18:1n-9 & $19.15 \pm 1.50^{\mathrm{a}}$ & $18.69 \pm 1.22^{\mathrm{a}}$ & $39.77 \pm 2.69^{\mathrm{b}}$ \\
\hline $18: 1 \mathrm{n}-7$ & $1.26 \pm 0.10^{\mathrm{a}}$ & $1.10 \pm 0.10^{\mathrm{a}}$ & $1.40 \pm 0.06^{\mathrm{b}}$ \\
\hline $18: 1 n-5$ & $0.06 \pm 0.01^{\mathrm{a}}$ & $0.05 \pm 0.01^{\mathrm{a}}$ & $0.07 \pm 0.01^{\mathrm{b}}$ \\
\hline $18: 2 n-6$ & $8.24 \pm 0.31^{\mathrm{a}}$ & $10.92 \pm 0.54^{\mathrm{b}}$ & $14.31 \pm 0.86^{\mathrm{c}}$ \\
\hline $18: 3 n-3$ & $0.37 \pm 0.02^{\mathrm{a}}$ & $0.40 \pm 0.03^{\mathrm{ab}}$ & $0.46 \pm 0.03^{b}$ \\
\hline $18: 3 n-6$ & $0.35 \pm 0.02^{\mathrm{a}}$ & $0.45 \pm 0.03^{b}$ & $0.30 \pm 0.01^{\mathrm{a}}$ \\
\hline $20: 3 n-3$ & $0.62 \pm 0.04^{\mathrm{a}}$ & $0.73 \pm 0.02^{\mathrm{b}}$ & $0.92 \pm 0.05^{\mathrm{c}}$ \\
\hline $20: 4 n-6$ & $1.37 \pm 0.06^{\mathrm{a}}$ & $1.49 \pm 0.03^{\mathrm{a}}$ & $1.47 \pm 0.10^{\mathrm{a}}$ \\
\hline $20: 5 n-3$ & $0.10 \pm 0.01^{\mathrm{a}}$ & $0.04 \pm 0.01^{\mathrm{b}}$ & $0.07 \pm 0.01^{\mathrm{c}}$ \\
\hline $24: 0$ & $0.15 \pm 0.01^{\mathrm{a}}$ & $0.36 \pm 0.01^{\mathrm{b}}$ & $0.24 \pm 0.02^{\mathrm{c}}$ \\
\hline 24:1n-9 & $0.45 \pm 0.01^{\mathrm{a}}$ & $0.82 \pm 0.03^{b}$ & $0.65 \pm 0.05^{\mathrm{c}}$ \\
\hline $22: 5 n-3$ & $0.14 \pm 0.01^{\mathrm{a}}$ & $0.08 \pm 0.01^{\mathrm{b}}$ & $0.06 \pm 0.01^{\mathrm{b}}$ \\
\hline $22: 6 n-3$ & $1.39 \pm 0.02^{\mathrm{a}}$ & $0.79 \pm 0.03^{\mathrm{b}}$ & $0.81 \pm 0.06^{\mathrm{b}}$ \\
\hline$n-6$ & $9.96 \pm 0.36^{\mathrm{a}}$ & $12.87 \pm 0.58^{\mathrm{b}}$ & $16.08 \pm 0.92^{c}$ \\
\hline$n-3$ & $2.62 \pm 0.02^{\mathrm{a}}$ & $1.63 \pm 0.03^{b}$ & $1.39 \pm 0.08^{c}$ \\
\hline$n-6 / n-3$ & $3.80 \pm 0.12^{\mathrm{a}}$ & $7.87 \pm 0.25^{\mathrm{b}}$ & $11.52 \pm 0.81^{\mathrm{c}}$ \\
\hline SFA & $13.84 \pm 1.02^{\mathrm{a}}$ & $12.71 \pm 0.23^{\mathrm{a}}$ & $16.41 \pm 0.90^{\mathrm{b}}$ \\
\hline MUFA & $23.08 \pm 1.57^{\mathrm{a}}$ & $22.56 \pm 1.39^{\mathrm{a}}$ & $44.24 \pm 2.86^{\mathrm{b}}$ \\
\hline PUFA & $12.59 \pm 0.38^{\mathrm{a}}$ & $14.90 \pm 0.62^{\mathrm{b}}$ & $18.39 \pm 0.99^{c}$ \\
\hline PUFA/SFA & $0.91 \pm 0.04^{\mathrm{a}}$ & $1.17 \pm 0.03^{\mathrm{b}}$ & $1.12 \pm 0.01^{\mathrm{a}}$ \\
\hline PUFA/MUFA & $0.55 \pm 0.02^{\mathrm{a}}$ & $0.66 \pm 0.03^{b}$ & $0.41 \pm 0.01^{\mathrm{c}}$ \\
\hline
\end{tabular}

Results expressed as mean \pm standard deviation for analysis in three replicates. Values with different letters in the same row are significantly different $(p<0.05)$ by Tukey's test; ST: standard diet; CAF: cafeteria diet; SFA: total saturated fatty acid; MUFA: total monounsaturated fatty acid; PUFA: total polyunsaturated fatty acid; n-6: total omega-6 fatty acid; n-3: total omega-3 fatty acid; n-6/n-3: omega-6/omega-3 ratio.

2.62 ( 0 days of supplementation) to $1.39 \mathrm{mg} \mathrm{g}^{-1}$ (60 days of supplementation). Suárez-García et al. ${ }^{24}$ observed a reduction of n-3 PUFA levels (alpha-linolenic acid and docosahexaenoic acid) in female Sprague-Dawley rats as a result of the ingestion of the CAF diet. This is explained because long-chain n-3 PUFAs decrease the production of pro-inflammatory eicosanoids from arachidonic acid and increase the production of anti-inflammatory eicosanoids with the objective of resolving acute inflammation. ${ }^{33}$ Obesity shows a persistent inflammatory profile due to the imbalance in favor of pro-inflammatory eicosanoids. ${ }^{34}$

\section{Conclusions}

The CAF diet presented a higher content of energy and lipids, and the majority fatty acids in the diet were oleic, linoleic and palmitic acids due to the addition of peanut, biscuit and chocolate. Due to these higher values, this diet can probably be used as a tool to induce obesity, even in 
zebrafish. These fatty acids found in higher concentrations were incorporated into the zebrafish fillets, indicating that feeding influences the lipid composition.

\section{Acknowledgments}

The authors would like to thank Coordenação de Aperfeiçoamento de Pessoal de Nível Superior (CAPES), Fundação Araucária de Apoio ao Desenvolvimento Científico e Tecnológico do Estado do Paraná (FAPPR) and Conselho Nacional de Desenvolvimento Científico e Tecnológico ( $\mathrm{CNPq}$ ) for their financial support and fellowships.

\section{References}

1. http://www.who.int/mediacentre/factsheets/fs311/en, accessed in November 2017.

2. Zeeni, N.; Hamalian, C. D.; Dimassi, H.; Faour, W. H.; Inflammation Res. 2015, 64, 501.

3. Montalbano, G.; Mania, M.; Guerrera, M. C.; Abbate, F.; Laurà, R.; Navarra, M.; Vega, J. A.; Ciriaco, E.; Germanà, A.; Ann. Anat. 2015, 204, 36.

4. Oka, T.; Nishimura, Y.; Zang, L.; Hirano, M.; Shimada, Y.; Wang, Z.; Umemoto, N.; Kuroyanagi, J.; Nishimura, N.; Tanaka, T.; BMC Physiol. 2010, 10, 21.

5. Forn-Cuní, G.; Varela, M.; Rodriguez, C. M. F.; Figueras, A.; Novoa, B.; J. Endocrinol. 2015, 224, 159.

6. Den Broeder, M. J.; Kopylova, V. A.; Kamminga, L. M.; Legler, J.; PPAR Res. 2015, 2015, 358029.

7. Meguro, S.; Hasumura, T.; Hase, T.; PLoS One 2015, 10, e0120142.

8. Leibold, S.; Hammerschmidt, M.; PLoS One 2015, 10, e0120776.

9. Simopoulos, A. P.; Nutrients 2016, 8, 128.

10. Pinto-Júnior, D. A. C.; Seraphim, P. M.; Rev. Nutr. 2012, 25 , 313.

11. Nguyen, M.; Yang, E.; Neelkantan, N.; Mikhaylova, A.; Arnold, R.; Poudel, M. K.; Stewart, A. M.; Kalueff, A. V.; Behav. Brain Res. 2013, 256, 172.

12. Yang, L. L.; Wang, G. Q.; Yang, L. M.; Huang, Z. B.; Zhang, W. Q.; Yu, L. Z.; Molecules 2014, 19, 2390.
13. Hasumura, T.; Shimada, Y.; Kuroyanagi, J.; Nishimura, Y.; Meguro, S.; Takema, Y.; Tanaka, T.; Nutr. Metab. 2012, 9, 73.

14. Siccardi, A. J. R. D.; Garris, H. W.; Jones, W. T.; Moseley, D. B.; D'abramo, L. R.; Watts, S. A.; Zebrafish 2009, 6, 275.

15. Cunniff, P. A.; Official Methods of Analysis of AOAC International, $16^{\text {th }}$ ed.; Association of Analytical Chemistry: Arlington, CD-Rom, 1998.

16. Bligh, E. G.; Dyer, W. J.; Can. J. Biochem. Physiol. 1959, 37, 911.

17. Karami, A.; Groman, D. B.; Wilson, S. P.; Ismail, P.; Neela, V. K.; Environ. Pollut. 2017, 223, 466.

18. Fowler, L. A.; Dennis, L.; Dawson, J. A.; Barry, R. J.; Davis, J. L.; Powell, M.; Yuan, Y.; Williams, M.; Watts, S.; FASEB J. 2017, 31, 19.

19. Figueiredo, I. L.; Claus, T.; Santos Jr., O. O.; Almeida, V. C.; Magon, T.; Visentainer, J. V.; J. Chromatogr. A 2016, 41, 1456.

20. Visentainer, J. V.; Quim. Nova 2012, 35, 274.

21. GraphPad Prism 5.0 Software; San Diego, USA, 2007.

22. Kala, A. L. A.; J. Food Sci. Technol. 2014, 51, 3520.

23. Ha, A. W.; Kim, W. K.; Kim, J. H.; Kang, N.; Nutr. Res. Pract. 2015, 9, 249

24. Suárez-García, S.; Del Bas, J. M.; Caimari, A.; Escorihuela, R. M.; Arola, L.; Suárez, M.; PLoS One 2017, 12, e0171970.

25. Cardoso, G. K.; Ginés, I.; Pinent, M.; Ardévol, A.; Terra, X.; Blay, M.; Br. J. Nutr. 2017, 117, 218.

26. Hariri, N.; Thibault, L.; Nutr. Res. Rev. 2010, 23, 270.

27. Martin, C. A.; Almeida, V. V.; Ruiz, M. R.; Visentainer, J. E. L.; Matsushita, M.; Souza, N. E.; Visentainer, J. V.; Rev. Nutr. 2006, 19, 761.

28. Brunetti, L.; Leone, S.; Chiavaroli, A.; Orlando, G.; Recinella, L.; Ferrante, C.; Dinisio, C.; Verrattp, V.; Vacca, M.; Int. J. Immunopathol Pharmacol. 2010, 23, 1073.

29. Abelti, A. L.; J. Nutr. Food Sci. 2017, 7, 574.

30. Kirwan, A. M.; Lenighan, Y. M.; O’Reilly, M. E.; McGillicuddy, F. C.; Roche, H. M.; Biochem. Soc. Trans. 2017, 45, 979.

31. Delgado, G. E.; Krämer, B. K.; Lorkowski, S.; März, W.; Von Schacky, C.; Kleber, M. E.; J. Clin. Lipidol. 2017, 11, 126.

32. Simopoulos, A. P.; J. Am. Coll. Nutr. 2002, 21, 495.

33. Burdge, G. C.; Calder, P. C.; Nutr. Res. Rev. 2006, 19, 26.

34. Calder, P. C.; Mol. Nutr. Food Res. 2008, 52, 885.

Submitted: August 25, 2017

Published online: November 27, 2017 